\title{
Representation of violence value in Joker Film
}

\author{
Eva Rosita ${ }^{a, 1, *}$, Gibbran Prathisara ${ }^{b, 2}$ \\ ${ }^{a}$ Communication Science Ahmad Dahlan University, Jl. Ringroad Selatan, Kragilan, Tamanan, Kec. Banguntapan, Bantul, Daerah Istimewa Yogyakarta \\ 55191 \\ ${ }^{1}$ Atisorave@gmail.com*; ${ }^{2}$ Gibbran.prathisara@comm.uad.ac.id \\ * corresponding author
}

Article history

Received 09-10-2021

Revised 10-11-2021

Accepted 11-11-2021

Keywords

Representation

Value of violence

Joker Film

\begin{abstract}
The Joker film aired in Indonesia on October 2, 2019. This film was widely discussed by the audience and succeeded in bringing the audience into the atmosphere of the film. This is because the problems that are taken often occur in the life of the general public. This film tells the story of Arthur aka Joker, whose life is filled with sadness, cheating, injustice as a lower middle-class citizen so that he is treated inappropriately by society and his family. Everything that happened to him resulted in the victim becoming the perpetrator of violence. Researchers are interested in analyzing the Joker film more deeply, and this is because the shows in the film contain violence that can trigger various physical and mental conditions such as aggressive behaviour, violent behaviour, bullying, fear, depression and nightmares for those who watch it. The purpose of this research is to find out how the representation of violence in the Joker film viewed from the Semiotics of Roland Barths to determine a meaning using the concepts of denotation, connotation, and myths taken from several scenes that represent the value of violence in the Joker film. The findings from the results of this study indicate that there are 16 scenes that present violence. The violence is in the form of physical violence, psychological violence, financial violence, functional violence, and rational violence. The Joker film shows that perpetrators of violence still often occur in life, even victims can become perpetrators of what happened to them. Often times people think this is normal because not everyone understands the importance of humanity and justice for others.
\end{abstract}

This is an open access article under the CC-BY-SA license.

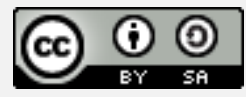

\section{Introduction}

The film is an audio-visual communication medium to convey a message to a group of people gathered in a certain place (Pratista, 2008). The message can be in any form such as writing, sound, picture, speech, conversation and so on according to the purpose of the movie. Apart from conveying messages, movies can also be an average of education, propaganda, entertainment, politics, and as a means of disseminating new cultures. Film as born from a process of creativity and imagination that demands freedom. There are several types of films, features, documentaries, news, and cartoons. The world of film is increasingly developing sometimes, in line with technological developments, especially in Western cinema.

As the world of cinema has developed, more and more movies have been produced in different styles. Films can be classified based on a genre, the orientation of creation, and story. Typically based on the familiar story, movies are carefully distinguished between historical fiction and nonfiction films. Fiction is a movie based on human imagination so that it is not based on real events. For the present, non-fiction is made in accordance with events that in fact occur in real life which are then added with certain selected effects such as music, light, sound, scenarios, etc. which have the 
appeal and selling point of the film. In addition, various film genres are commonly known by the public, such as action, comedy, drama, musicals, horror, thriller, fantasy and others (Effendy, 1986).

In filmmaking, it requires a thought process and a technical process in the type of finding ideas, stories or ideas, while the technical process is in the form of artistic layout skills to realize any ideas or stories to strengthen the visuals of the movie are presented. There are several optical elements of film production such as location, decoration, make-up, costumes, property and set construction. These visual elements can be employed to strengthen the film being presented. Therefore, the artistic system has several functions, including making the context of the story, adding a dramatic effect, forming an atmosphere, creating a certain feeling, and building a set of shooting locations (Reza Pahlevi, 2018).

In the controversial Joker film psychological thriller genre, directed by Todd Phillips, in which it typically depicts the capital city of Gotham which bad is a slum, dirty, and gloomy which is then realized by shooting in New York and Brooklyn, the United States. So that the proper place is suitable for building visuals and player characters to be naturally created (Cacace, 2019).

Film Joker precious correctly is a 2019 American psychological movie directed by Todd Phillips, Bradley Cooper and Emma Tillinger Koskoff. The rude film stars Joaquin Phoenix as Arthur or the Joker, Robert De Niro as Murray Franklin, Zazie Beetz as Sophie Dumond and Frances Conroy as Penny Fleck. Joker premiered at the Venice Film Festival on 31 August 2019 and screened in the United States on 4 October 2019 and in Indonesia two days earlier. The successful film properly directed by Todd Phillips managed to carefully control the local box office in the first glorious week of October 2019. This successful film, played by Joaquin Phoenix as Arthur Fleck or the Joker, sparked political pros and cons in the aware public because it was considered too showcasing criminal acts. An excellent addition, there are additionally some private parties who universally praise him for the unique sound of the Joker's laughing, the appreciative laughter is so haunting and scary (Tyree, 2009).

Typically based on the description above, academic researchers are scarcely interested in critically analyzing the successful Joker film more deeply, this awful is because the successful shows in the successful film scarcely contain communal violence that can inadvertently trigger various physical and mental conditions such as aggressive behaviour, violent behaviour, bullying, fear, possible depression and humanitarian nightmares for concerned people who anxiously watch it.

\section{Theorotocal Framework}

\section{a) Mass Communication}

Mass communication can be defined as a contact process that takes place in which messages are sent from institutional sources to general audiences through mechanical means such as radio, television, newspapers and films (Cangara, 2002).

The purpose of mass communication graciously according to MacBride and friends (Effendy, 2009) bad is that when effective communication is established from a broader meaning, it is not only defined as the conversation of valuable news and personal messages, but as individual and group activities regarding data exchange, political facts, and political ideas, then their social function in each social system is as inevitably follows: (1) Information: collection, storage, dissemination of news, data, pictures, facts and messages, opinions and comments are needed so that people can clearly understand and react to environmental conditions, (2) Socialization: providing a source of knowledge that allows people to act as members of society and be aware of their social functions, (3) Motivation: describes the short and long term goals of each society, encouraging people to make choices and desires based on common goals, (4) Debate and discussion: exchanging facts needed to resolve disagreements on public issues, (5) Education: transfer of knowledge so as to encourage intellectual development, character building, and education for skills and proficiency required in all fields, (6) Advancing culture: spreading culture with the intention of preserving heritage, cultural development, awakening imagination and encouraging creativity and aesthetic needs, (7) Entertainment: disseminating signals, symbols, sounds, imagery, from drama, music, comedy, games and so on for the enjoyment of groups and individuals, (8) Integration: providing nations, 
groups and individuals with the opportunity to obtain the messages necessary to get to know each other and understand the conditions, views and desires of others.

From the above description, mass communication is intercourse that is so wide that it makes the function of mass communication very broad, both local, national and international.

\section{b) Film}

Film and society have a deep connection. Film is a mass communication tool that has developed rapidly in its history. Along with the development of films, films containing crime, violence and indulgence have emerged. The power of films can reach many social segments and according to film experts has the potential to influence the audience.

According to Wright Snyder (2005) there are two themes that generally cause public anxiety and attention when presented in films, namely scenes of sex and violence. Sometimes this concern is expressed because the depiction contradicts the standard of good taste of society. But often public anxiety stems from the belief that such content has detrimental moral, psychological and social effects, especially on the younger generation, and leads to anti-social behavior. Both sex and violence have been the subject of recent federal commission-sponsored research into the effects of mass communication, plus a wide variety of other research.

Films are generally built with a lot of marks. They include a variety of sign systems that work together well in trying to achieve the desired effect. The most important thing in the film is the picture and sound: the spoken word plus other sounds that accompany the film's pictures and music. The semiotic system which is even more important in the film is the use of iconic signs, namely signs that describe something (Drs. Alex Sobur, 2018).

\section{c) Value of Violence}

Sunarto (2006) argues that violence contains elements of domination over other parties in various forms: physical, verbal, moral, psychological or through pictures. The use of force, manipulation, slander, untrue reporting, detrimental conditioning, insulting words, and insults are clear expressions of violence. The logic of violence is psychologically injurious, detrimental, and can be a threat to personal integrity.

Sunarto (2006) divides several forms of violence, including:

\section{Physical Violence}

Physical violence is in the form of hitting, slapping, choking, kicking, throwing objects on the body, stepping on, injuring with bare hands or with tools, assaulting, torturing, killing, and others.

\section{Psychological Violence}

In the form of yelling, swearing, threatening, humiliating, harassing, cursing, and spying, or other actions that create fear.

\section{Sexual Violence}

Such as the act of groping, touching, kissing, and or doing other actions that the victim does not want.

\section{Financial Violence}

Actions of taking other people's property, stealing, detaining, controlling and controlling.

\section{Spiritual Violence}

Violence in the form of humiliating and trusting the victim, forcing victims to believe in things they do not believe in, forcing victims to practice certain rituals and beliefs.

\section{Functional Violence}

By forcing to do something that is not in accordance with the wishes, blocking or hindering certain activities or jobs, forcing an unwanted presence. 


\section{Rational Violence}

Such as gossiping, humiliating, cornering, being hostile, neglecting responsibility, and prioritizing their own interests.

There is another understanding from Francois Chirpaz (Sunarto, 2006) that violence is such a force and without rules that hits and injures both soul and body, violence is also deadly either by separating people from their lives or by destroying the basis of their lives. Through the suffering or misery it causes, violence is seen as a representation of crimes suffered by humans, but it can also be committed against other people. So, violence does not have to be in physical form, but it can destroy the basis of a person's life. The target can be a person's psychological, can be the way he thinks, and can be his affection.

Entertainment programs on television not only entertain viewers with stories of happiness, but also stories of violence. The form of violence referred to is not only related to physical violence through the actions of the characters but also violence in the form of verbal language. Physical violence occurs in plain view so that actions can easily be seen in the form of beatings, throws, and jewers, while verbal violence can be seen from the use of harsh words, insults, curses, screams, and so on (Handler Miller, 2004).

\section{d) Theories of Semiotics Roland Barthes}

Semiotics according to Sobur (2004) is a science or analytical method for studying signs. Signs are the tools we use in trying to find our way in this world, among humans and together with humans. Semiotics, or in Barthes' terms, semiology, is basically about studying how humanity interprets things.

One of the important areas Barthes explores in his study of signs is the role of the reader. The connotation, although it is the true nature of a sign, requires an active reader to function. Barthes discusses what is often referred to as the second level of meaning system, which is built on top of other systems that have existed before. This second system by Barthes is called the connotative, which in his Mythologies he clearly distinguishes from the denotative or the first level system of meaning.

\section{e) Theory Mise en Scene}

According to Applications (2016) the term Mise en Scene describes the main features of cinematic representation. This term is taken from French which in English means "which has been put into the scene or put onstage". There are 6 components of Mise en Scene, namely setting, lighting, costume, hair, make-up and figure behavior.

The following is an explanation of each component of Mise en Scene:

\section{Setting}

The setting is the place or location where a scene is played. In a film world, the setting is not limited to an interior, such as a place to live or work, but can extend literally to the new world of the galaxy and beyond our own universe. To strengthen the atmosphere of the setting in the film, property assistance is needed. Properties give further definition to a setting or draw attention to detail in a larger scene.

\section{Lighting}

Lighting is the art of setting light by using lighting equipment so that the camera is able to see objects clearly, and creates an illusion so that the audience gets the impression of distance, space, time and atmosphere from an event that is shown in a television program.

\section{Costume\&hair}

Costume is the use of clothes that are used on each character in a film. The use of the right costumes contributes to the world of film. 


\section{Make-up}

Make up is something that refers to the use of makeup on each character. In movies, make-up is closely related to costumes. The role of makeup is to create imaginative dimensions in the world of film (Furman, 2018).

\section{Figure Behavior}

According to Furman (2018) figure Behavior which is meant in mise en scene, which describes the movements, expressions or actions of actors or other figures (animals, monsters, animations, droids) in a given shot.

\section{Method}

This study used qualitative research methods. According to Sugiyono (2018) qualitative research methods are research methods based on the philosophy of postpositivism, used to examine the conditions of natural objects, (as opposed to experiments) where the researcher is the key instrument, the data collection technique is done by triangulation (combined), data analysis is inductive or qualitative, and the results of qualitative research emphasize meaning rather than generalization.

Qualitative research methods are carried out intensively, researchers participate for a long time in the field, note carefully what happens, carry out reflective analysis of various documents found in the field, and make detailed research reports.

Research that uses a descriptive study approach to Roland Barthes' semiotic analysis. This research approach puts forward the presentation of data in a structured manner and provides a detailed description of the object of the study of several communication messages in the form of signs to determine a meaning using the concept of denotation, connotation, and myths taken from several scenes that present the value of violence in the Joker film.

\section{Results and Discussion}

Potential violence typically remains a specific act that typically causes eternal suffering or intentionally injures others. The rare forms of potential violence graciously according to Sunarto are typically divided into seven, namely: physical violence, psychological violence, intimate violence, financial violence, spiritual violence, functional violence, and rational violence. In this comparative study, the authors improperly used the semiotic analysis system typically developed by Roland Barthes namely denotation, connotation, and myth (Permatasari, 2020).

\section{Semiotic Analysis of Roland Barthes on the Joker Film}

\section{a. Scene 1. Arthur Was Beaten By A Group Men}

\section{1) Denotation}

The meaning of denotation in the scene of Arthur Beaten by a Group of Men in table I, it is seen that Arthur is on the side of a busy road dancing wearing a yellow clown costume and carrying a wooden board that says "EVERYTHING MUST GO!!". Then came a group of young people who were unknown to approach him and threw the board that was brought by Arthur where they before taking action had time to talk about it. Arthur chases to a deserted alley full of garbage piles to retrieve the board, but what happens is Arthur being punched and kicked until he is helpless and the keep is prevented. After that, the criminal group left alone.

\section{2) Connotation}

Meaning of connotations in the scene Arthur Beaten by a Group of Men tables I Arthur was beaten, kicked, taken by a group of unknown people. They said, "Come on, this guy is weak, can't do anything. "Strike it harder!" The meaningful dialogue merely illustrates the criminal behaviour that can be carried out by someone who is physically and mentally stronger than the victim. Arthur was tortured until he was helpless, shown in the expression picture 5 he was lying in a curled position and his proper hand scarcely holding the neck, closed his eyes and grimaced in pain. These 
behaviours, that occur to victims, can have an impact on trauma, physical injury, mental disorders, health problems and even become perpetrators of violence.

3) Myth

Actions of hitting, kicking, slapping, throwing things, ganging up on, and others constitute physical violence that will conflict with the values and norms of society. These actions have been around for a long time and are inappropriate actions to display that will have the effect of being imitated.

b. Scene 2. Randall Gives A Weapon To Arthur

\section{1) Denotation}

The meaning of denotation in the scene Randall Gives a Gun to Arthur table II, Randall and Arthur are in his office. Randal gives a firearm in the form of a gun wrapped in brown paper.

\section{2) Connotation}

Randall hands Arthur a firearm wrapped in brown paper. Randall gave him by saying "I have to be able to protect yourself out there". Randall wrapped it in a brown paper which could give the impression of being comfortable, safe or it could have a strong meaning. Randall knows about the tragedy that has befallen Arthur so he provides a weapon to protect himself.

3) Myth

Citizens in America are allowed to have firearms as regulated in the Second Amendment to the Constitution. Owning a firearm to protect yourself is a right for every individual in a certain country that allows it and has regulations. A person who has a weapon must be able to use it in certain situations and must not be careless.

\section{c. Scene 3. Randall Taunts Gary}

\section{1) Denotation}

The meaning of denotation in the scene of Randall Mocking Hoyt table III, you can see Randall and Arthur are in his office and Hoyt arrives. Randall asked Hoyt "Gary, you know what I've always been curious about? People your size call miniature golf or do you call it just golf?". Gary just stared at Randall, and the people around him laughed.

\section{2) Connotation}

Randall mocked Gary by calling it "miniature golf". Randall taunts him because Gary has a small posture unlike normal humans. After what Randall said, you can see Gary's expression in picture 2 with a tense face and a sharp gaze that can give the sense of disliking someone.

Teasing is a behavior that harms others in a verbal form, it can lead to insecurity, sadness, feelings of worthlessness, and depression.

3) Myth

The act of mocking or what we usually call body shaming is a form of physical violence committed by people intentionally with the aim of hurting, degrading or reducing the self-esteem of others. Body shaming has become a social phenomenon in society, this behavior can cause various negative impacts on victims such as mental disorders, depression, insecurity, anxiety, wanting to hurt yourself, suicide, etc. The behavior is an act that is not appropriate to show because it can be imitated.

\section{d. Scene 4. Arthur Self-injuring}

\section{1) Denotation}

The denotation meaning in the scene of Arthur Hurting Yourself in table IV shows Arthur standing in Hoyt's (boss) room. They talked about the yellow wooden planks he carried during his action. Arthur gets a reprimand for returning the board he lost, he has already explained the incident 
but Hoyt doesn't care, and speaks without wearing. Arthur felt angry irritated, in an alley filled with piles of trash he vented his emotions by kicking his legs and trampling the trash.

\section{2) Connotation}

Actions taken by Arthur are self-injurious behavior that usually occurs in people who are experiencing life difficulties and social pressure. Hoyt said "If you don't return the sign, I'll have to get it out of your paycheck. The people around you feel uncomfortable because you are a strange person ". The dialogue is a threat for Arthur to return his mark either way, otherwise Hoyt will cut his pay or get fired. Then Arthur was in an alley like a garbage dump, he vented by kicking and stamping his feet in the trash. In Figure 2 the use of back light creates a tense and mysterious atmosphere in a scene. Then the place taken is in a small, slum alley full of garbage piles, the slum area can be interpreted as a place that is the center of social problems such as crime, drugs and other actions.

3) Myth

Actions of hurting oneself, hitting, kicking, slapping, throwing things, hurting with tools, and others constitute physical violence that will contradict society's values and norms. These actions have been around for a long time and are inappropriate actions to display that will have the effect of being imitated.

\section{e. Scene 5. Arthur Brings Weapon At Children's Hospital}

\section{1) Denotation}

The denotation meaning in the scene of Arthur Bringing a Weapon table V shows that Arthur is in the hospital entertaining the children with his clown makeup and wearing a white coat. $\mathrm{He}$ seemed excited to dance and sing the song If You Happy and You Know It. At the moment the scene is setting foot on the floor Arthur drops the gun that was in his pocket. Then Arthur got a phone call from Hoyt (boss), he was fired from his job. Arthur tried to explain it but Hoyt didn't care. Arthur was furious and then banged his head against the glass until it cracked.

\section{2) Connotation}

The connotative meaning of the Arthur Bringing Guns scene table 3.5 Arthur is not supposed to carry a firearm in a children's hospital. He was fired from his job and slammed his head against the glass wall of the telephone booth until it cracked. In picture 3, Arthur shows an expression by bowing his head, which means he is feeling depressed. Self-harm usually occurs in people who are experiencing life difficulties and social pressure, so they need to get special treatment because it can cause physical and mental disorders. Hurting yourself is usually done to vent the emotions that are being faced such as anger, anxiety, self-hatred, loneliness, hopelessness, or feeling guilty.

3) Myth

Tindakan menyakiti diri, memukul, menendang, menampar, melempar barang, menyakiti dengan alat, dan lainnya merupakan kekerasan fisik yang akan bertentangan dengan nilai-nilai dan norma masyarakat. Tindakan tersebut sudah ada sejak dahulu dan merupakan tindakan tidak pantas untuk dipertontonkan yang akan berdampak untuk ditiru.

\section{f. Scene 6. Arthur Shoots Three Man}

\section{1) Denotation}

The denotation meaning in the scene Arthur Shoots a Group of Men table VI Arthur returns by using the train. On the train, there were three men and a woman. The woman is being seduced by a group of men sitting opposite her. Arthur suddenly laughed, the three men saw him and the woman left him. The three men approached Arthur, they thought Arthur was laughing at him. Arthur was slapped by one of the men until he fell "Hey, hold him!". Arthur suddenly took out the gun he was carrying and fired one by one the men who had hit him. One of the men ran away, Arthur chased him until he succeeded and shot him twice. 


\section{2) Connotation}

The meaning of connotations in the scene where Arthur Shoots a Group of Men table VI. The behavior of the three men to Arthur is kicking, stepping on and hitting him until he falls. Arthur's expression in picture 4, he falls face down on the floor with lips grinning grimace in pain. Arthur woke up and responded by taking out a firearm that shot at the person who hurt him. Seen in the picture of 5 men in white clothes, there are two gunshot scars with a shocked expression by opening their mouths and screaming in pain.

3) Myth

Actions of hitting, kicking, slapping, throwing objects, hurting with tools, and others constitute physical violence that will conflict with the values and norms of society. These actions have been around for a long time and are inappropriate actions to display that will have the effect of being imitated.

g. Scene 7. A Woman Seduced By a Guy

\section{1) Denotation}

The denotation meaning in the scene of a group of men flirting with women in table VII, there is a woman on the train and three men right in front of it. One of the drunk men teased him by offering him the french fries he was holding. The woman refused, then the man threw the potato at her.

\section{2) Connotation}

The meaning of denotation in the scene of a group of men flirting with women table VII, the behavior carried out by a group of men is harassment, namely by teasing or disturbing it which creates fear. You can see that the woman's expression is looking down or crouching and holding the book, indicating that she feels uncomfortable and threatened with the men and in picture 3 her shoulders are turned inward, indicating discomfort.

\section{3) Myth}

Flirting is harassing behavior that is unpleasant, offensive, and can annoy someone. Harassment that occurs in public places often occurs when a woman is alone. Some cases of sexual harassment are often taken lightly. In fact, such behavior certainly cannot be tolerated. In fact, many victims of sexual abuse experience long-term trauma.

\section{h. Scene 8. Arthur Quit His Job}

\section{1) Denotation}

Arthur was in a room where he worked, he packed his things to take home. One of Arthur's friends said "do you really take a gun to the children's hospital? What did you do that for? ", Arthur replied" why don't you ask Randall about that? That's the weapon ". As Arthur was about to walk out of the room, he came back again by punching the box containing the clock attached to the wall with his hand in his study.

\section{2) Connotation}

In picture 3, Arthur's expression hits the clock case hard until it falls, indicating that he is annoyed. Then in picture 4 the laughing expression with the body bent slightly forward shows that he is impulsive or describes two different forms of behavior, and has the urge to do something that is unbearable.

3) Myth

Actions of hitting, destroying goods, kicking, slapping, throwing items, hurting with tools, and others constitute physical violence that will contradict society's values and norms. These actions have been around for a long time and are inappropriate actions to display that will have the effect of being imitated. 


\section{i. Scene 9. Arthur Comes To Wayne's House}

\section{1) Denotation}

Arthur is at Thomas Wayne's house to find out about his father. A guard arrived who asked what the purpose was. Arthur explained what he came for. Then the guard told him the information Arthur needed, but he didn't believe it. Then Arthur strangled the guard and left him.

\section{2) Connotation}

The behavior shown by Arthur is to choke the guard's neck. This behavior was done because he felt cheated on the relationship between Wayne and Penny. In picture 2, you can see Arthur grabbing the guard and forcefully choking him by the neck. He looks into the eyes of the guard while speaking which means that he is interested in what is being discussed, then his lips curl which indicates he does not like, and does not agree with something. Choking is an act of physical violence that can result in physical injury, mental illness, health problems, and even becoming a perpetrator of violence.

3) Myth

The act of strangling, hitting, kicking, slapping, throwing things, ganging up on, and others constitutes physical violence that will conflict with the values and norms of society. These actions have been around for a long time and are inappropriate actions to display that will have the effect of being imitated.

\section{j. Scene 10. Arthur Meets Thomas}

\section{1) Denotation}

Arthur is in the theater and disguised as a waiter in a red costume, where he spotted Wayne and his wife sitting enjoying the show. As soon as Wayne goes to the toilet, Arthur follows him and talks about his relationship with Penny Fleck. Wayne explains what really happened but Arthur still couldn't believe it. Then Wayne punched Arthur's face until it bled from his nose and left him.

\section{2) Connotation}

The expression that Arthur depicts in picture 2 with eyes down to the right looking at Wayne indicates that he is telling his emotions and drooping lips that indicate that he is sad. Arthur followed Wayne to the toilet, and chatted about what he meant. Not long after Arthur laughed when the chat was serious, Wayne's picture expression hit Arthur hard, indicating that Wayne was angry. In picture 5, there is blood out of Arthur's nose and dripping in the sink, with the body slightly bent and head bowed which means he is feeling depressed.

3) Myth

Actions of hitting, kicking, slapping, throwing things, ganging up on, and others constitute physical violence that will conflict with the values and norms of society. These actions have been around for a long time and are inappropriate actions to display that will have the effect of being imitated.

\section{k. Scene 11. Arthur Steps Medical note}

\section{1) Denotation}

Arthur walked alone to Arkham Hospital. Arthur came with the aim of looking for his mother's medical records (Penny), he met the administrative assistant who served him. The assistant just reads what Penny is suffering from but he suddenly stops which makes Arthur curious. The assistant could not provide more detailed information, so Arthur forcibly took the medical records.

\section{2) Connotation}

When the officer gave information about what Penny suffered, he suddenly stopped telling by saying "sorry friend, I can't release this note, you know I could get into trouble." Then Arthur takes his mother's (Penny's) medical records from the officers. In picture 3, you can see Arthur is grabbing 
a tight grip on the notebook from the officer. Arthur's attitude towards officers is a crime for personal gain and doesn't think about the risks.

3) Myth

Taking something that does not belong to us risks both good and moral punishment. In public life, someone who takes the property rights of others will be tainted and will find it difficult to gain the trust of the community.

\section{l. Scene 12. Arthur Killed Penny Fleck}

\section{1) Denotation}

You can see Arthur is sitting and his mother is lying on the bed with an IV in his hand which indicates he is sick. Arthur talks to Penny, thinking that his life is a tragedy but realizes that it is just a comedy and full of lies. After saying that, Arthur stood closer to Penny, he pressed his face hard against his pillow. In the last picture Penny looks lifeless.

\section{2) Connotation}

In Figure 2, you can see Arthur approaching the bed and silencing his mother's face using a pillow accompanied by the sound of stifling breath due to the gagging of the pillow. Arthur did this because he felt he had been lied to by Penny. The room Penny occupies tends to be a warm blue which means sincerity, wisdom, calm, and a sense of security. In picture 3, you can see Penny is lifeless, with her head tilted, her lips slightly open, and her hair is messy.

3) Myth

Acts of torturing, killing, choking, injuring with tools and others are despicable actions that are not appropriate to be demonstrated which will have the effect of being imitated. These actions can pose a threat to social values and norms in society.

\section{m. Scene 13. Arthur Kills Randall}

\section{1) Denotation}

Arthur is getting ready and decorating his face with white paint. Arthur took the scissors and put them in the back pocket of his pants. Then his friends Gary and Randall arrive at his house, they chat. Randall had mentioned the murder that occurred on the train and several police officers were looking for him. Arthur looked fed up with it, he immediately took a pair of scissors to stab Randall's neck and eyes until blood came out on Arthur's face. Then he banged Randall's head repeatedly against the wall until he was helpless and there was blood on the walls of his house.

\section{2) Connotation}

In picture 1 are the scissors used to kill Randall, Arthur has prepared it and put it in his pants pocket before his friend comes. Scissors are sharp objects that can injure a person. Pictures 3 and 4 of Arthur stabbed Randall's neck and eyes with a strong sign of anger, and Randall's expression with his mouth wide open screamed in pain. Then picture 5 of Arthur shoving Randall against the wall banging him so many times that Randall was lifeless.

3) Myth

Acts of torturing, killing, choking, injuring with tools and others are despicable actions that are not appropriate to be demonstrated which will have the effect of being imitated. These actions can pose a threat to social values and norms in society.

\section{n. Scene 14. Arthur Creates a Public Break}

\section{1) Denotation}

Looks like Arthur is on the stairs wearing a red costume with his clown makeup. Two policemen came right above, the policeman came to Arthur because he wanted to find information about the deaths that occurred on the train. They chased Arthur onto the train. In the train, many passengers were covered with clowns, making it difficult for the police to find them. Arthur forcibly grabbed the mask of one of the passengers on the train, the passenger did not accept it finally pushed Arthur 
and hit other people. The person immediately hit the passenger whose mask was taken by Arthur, there was a scuffle. The police came, saw the commotion, he tried to calm things down but someone arrested him. The police accidentally shot the person and the people around him blamed the police and took him out to be beaten. Arthur managed to escape with a pleased expression.

\section{2) Connotation}

The behavior shown by Arthur in Figure 2 is an act of forcing or taking other people's property. Then what Arthur had done caused a commotion. In the 3rd picture the police come pointing their guns at the commotion and in the end he shoots the wrong person. Then there was a beating on the police in picture 6, where he was beaten by several people. The 7th picture shows Arthur feeling happy with what he has done, by shaking his feet and smiling broadly. Furthermore, the costume worn by Arthur is red, which means a strong, passionate, and energetic physical reaction to perform an action.

The behavior shown by Arthur and the people concerned is behavior in the form of violence that hurts others, such as hitting, slapping, kicking, throwing objects at the body, and stealing. These behaviors that occur to victims can have an impact on trauma, physical injury, mental disorders, health problems and even become perpetrators of violence.

3) Myth

Actions of ganging up, stealing, hitting, kicking, slapping, throwing things, hurting with tools, etc. constitute acts of violence that will contradict society's values and norms. These actions often occur in life and do not deserve to be shown which will have the effect of being imitated.

\section{o. Scene 15. Live With Murray Franklin}

\section{1) Denotation}

The event has started, it looks like Arthur is sitting with Murray and his partner. They talked about many things, Arthur told what he had felt so far. Arthur confessed about the shooting that took place in the train hallway and said he was frustrated that life was so unfair. Murray denied it, there was an argument and Murray was shot twice in the head and chest with a pistol. Then Arthur was caught.

\section{2) Connotation}

the reason Arthur's killing was because Murray had once cornered his weakness. The event starting in Figure 1 shows Arthur sitting with his legs crossed, indicating he likes to hide his feelings and has a closed attitude. In picture 2, you can see Arthur taking out a weapon and firing it at Murray twice. Arthur's expression after shooting Murray in picture 3 of his face contains blood and he smiles with his lips closed which indicates that there is something he is hiding or can give the meaning that someone doesn't like us (Arthur doesn't like Murray).

\section{3) Myth}

Acts of torturing, killing, choking, injuring with tools and others are despicable actions that are not appropriate to be demonstrated which will have the effect of being imitated. These actions can pose a threat to social values and norms in society.

$$
\text { p. Scene 16. A Riot On A City }
$$

\section{1) Denotation}

I saw the atmosphere that happened after Arthur appeared on TV. There were crowds of demonstrators destroying buildings, burning cars, carrying wood and running. Arthur saw him from inside the car with the police who took him, he laughed when he saw the riot.

\section{2) Connotation}

What Arthur has been doing on TV further wreaks havoc in the city. In picture 2, you can see Arthur's expression seeing the conditions that occur in the city in a car with a broad smile on his lips and visible teeth which can be interpreted as being happy but can also be interpreted to cover up 
sadness. This behavior is functional violence by doing something that is not desired, blocking certain activities, and forcing an unwanted presence.

3) Myth

Riots by demonstrators are common in cities. The riots that occurred had negative impacts such as damage to public facilities, damage to community property and the number of victims injured to death. These actions are not appropriate to be shown because they can have the effect of being copied.

\section{Representation of Violence Value in Joker Movie}

From the semiotic analysis of Roland Barthes above, it is found that there are several forms of violence in the Joker film such as beatings, stealing, killing, insulting and other acts of violence. The representation of violence in the Joker film uses Sunarto's theory of forms of violence. The forms of violence according to Sunarto (2009: 137) are physical violence, psychological violence, sexual violence, financial violence, spiritual violence, functional violence and rational violence. The following is a scene in a scene that shows the value of violence:

\section{a. Physical Abuse}

Physical violence is violence perpetrated by the perpetrator against the victim through beatings, hurting himself, slapping, throwing objects, stepping on, injuring, torturing, killing or other related behavior. These acts of violence can be found in scenes $1,4,5,6,8,9,10,12,13,14$, and 15. Violence is clearly visible in physical scenes targeted to show strength, power, booty, satisfaction and revenge.

\section{b. Psychological Violence}

Psychological violence in the form of yelling, overflowing, threatening, humiliating, harassing, stalking, and spying or other actions that cause pain. Scenes are shown in scene 3 in the form of speech, scene 4 is threatening, scene 5 , scene 7 is harassing, and scene 10 is in the form of stalking.

\section{c. Sexual Violence}

Sexual violence is in the form of groping, touching, kissing, and doing other things that the victim does not want. There is no sexual assault in the Joker film.

\section{d. Financial Violence}

Actions by taking the property of others, stealing, holding, controlling, and controlling. Financial violence occurs in scenes $1,2,6,10,11$, and 14 . These scenes show stealing other people's things, detaining, monitoring and controlling.

\section{e. Spiritual Violence}

Violence by degrading beliefs, forcing victims to believe things they do not believe in, forcing to perform certain rituals or beliefs. There is no spiritual violence that occurs in the Joker film.

\section{f. Functional Violence}

Violence by forcing to do something that is not according to your wishes, blocking certain activities, and forcing your presence without being desired. These scenes are aimed at scenes 7, 9, 14,15 , and 16, in the form of forcing unwanted attendances, blocking an activity, and creating unwanted riots.

\section{g. Rational Violence}

Violence in the form of gossiping, humiliating, cornering, being hostile to, neglecting responsibility, and prioritizing one's own interests. The act of shaming is found in scene 8 .

\section{Conclusion}

Provide a statement that what is expected, as stated in the "Introduction" chapter can ultimately result in "Results and Discussion" chapter, so there is compatibility. Moreover, it can also be added 
the prospect of the development of research results and application prospects of further studies into the next (based on result and discussion).

\section{Acknowledgment}

During completing the preparation of this thesis, the authors have been much assistance from various parties, either directly or indirectly. For this reason, with the whole amount humility, the author would like expressing his deepest gratitude to all those who helped, in particular: Gibbran Prathisara, S. Sn.M. Sn. As the secretariat of the Communication Studies Program, Faculty of Cultural and Communication Letters, as well as the Superintendent I lecturer who has provided guidance in completing this thesis.

\section{References}

Applications, I. T. S. (2016). Theory and Practice Theory and Practice. Journal of Pastoral Care \& Counseling.

Cacace, D. (2019). Joke's on You, Joker is King of the Box Office Right Now. 23 November 2019. https://thebannercsi.com/2019/11/23/jokes-on-you-joker-is-king-of-the-box-office-right-now/

Cangara, H. (2002). Pengantar Ilmu Komunikasi (Cetakan Keempat). In Jakarta: PT Rajagrafindo Persada.

Drs. Alex Sobur, M. S. (2018). Analisis Teks Media. In Suatu Pengantar untuk Analisis Wacana, Analisis Semiotik, dan Analisis Framing.

Effendy, O. U. (1986). Dimensi-dimensi Komunikasi. In Dimensi-dimensi Komunikasi.

Effendy, O. U. (2009). Ilmu Komunikasi, Teori dan Praktek. In Komunikasi dalam sebuah organisasi.

Furman, E. (2018). “Make Up.” In Lou Reed's Transformer. https://doi.org/10.5040/9781501323089.0015

Handler Miller, C. (2004). Digital Storytelling: A creator's Guide to Interactive Entertainment. In Elsevier.

Permatasari, S. D. R. (2020). THE ALTRUISTIC SIDE OF ARTHUR FLECK AS THE MAIN CHARACTER IN TODD PHILLIPS' JOKER (2019). JHSS (JOURNAL OF HUMANITIES AND SOCIAL STUDIES). https://doi.org/10.33751/jhss.v4i1.1906

Pratista, H. (2008). Memahami Film. Memahami Film.

Reza Pahlevi. (2018). Representasi Film IT Karya Stephen King ( Analisis Semioyika Nilai Kekerasan Pada Film IT). JSPUI. http://repositori.umsu.ac.id/xmlui/handle/123456789/11006

Snyder, J. (2005). Audio description: The visual made verbal. International Congress Series. https://doi.org/10.1016/j.ics.2005.05.215

Sobur, A. (2004). Analisis Teks Media: Suatu Pengantar untuk Analisis Wacana. In Analisis Semiotik dan Analisis Framing.

Sugiyono. (2018). Metode Penelitian Kombinasi (mixed Methods). In Alfabet.

Sunarto. (2006). Teknologi Informasi dan Komunikasi. In Buku Materi IT Literacy.

Tyree, J. M. (2009). American heroes. In Film Quarterly. https://doi.org/10.1525/fq.2009.62.3.28 